\title{
The impact of global trends on Serbian foreign trade $^{3}$
}

\author{
Article history: \\ Received: 8 August 2020 \\ Sent for revision: 2 December 2020 \\ Received in revised form: 14 December 2020 \\ Accepted: 20 December 2020 \\ Available online: 31 December 2020
}

\begin{abstract}
This paper analyzes the current key processes in the global economy: decline in international trade, rising protectionism and shortening of global production chains. The specific aim is to determine the effects of these global trends on Serbian foreign trade. The proposed hypotheses are 1) Decline in the volume of Serbian foreign trade can be expected to be sharper than global indicators and 2) The reduced volume of trade both in Serbia and globally will tend to continue for many years to come. Using statistical analysis for different types of data, linear regression and case study, the research has confirmed the first hypothesis. The coefficients obtained bz linear regression were applied to the WTO projections for global trade in 2020 and 2021. It was found that the expected decline in Serbia's foreign trade is almost twice the world average. The second hypothesis is proven by the analysis of the economic causes of the main global trends, which have proven to be structural to the greatest extent, hence long-term.
\end{abstract}

Keywords: international trade, protectionism, global value chains, foreign value added, Serbia

\footnotetext{
${ }^{1}$ Institute of International Politics and Economics, Belgrade, natasa.stanojevic@diplomacy.bg.ac.rs

${ }^{2}$ Faculty of Economics and Informatics Dositej, Belgrade

${ }^{3}$ The paper presents findings of a study developed as a part of the research project "Serbia and challenges in international relations in 2020 ", financed by the Ministry of Education, Science, and Technological Development of the Republic of Serbia, and conducted by Institute of International Politics and Economics, Belgrade.
} 


\section{Uticaj globalnih trendova na spoljnu trgovinu Srbije}

Apstrakt: Ovaj rad analizira aktuelne ključne procese u globalnoj ekonomiji: pad međunarodne trgovine, rast protekcionizma i skraćivanje globalnih proizvodnih lanaca. Specifični cilj je da istraži uticaj ovih kretanja na srpsku spoljnu trgovinu. Predložene hipoteze su 1) Može se očekivati da će pad obima srpske spoljnotrgovinske razmene biti oštriji od globalnih pokazatelja i 2) Smanjeni obim trgovinske razmene, kako u Srbiji, tako i na globalnom nivou, nastaviće se u dužem periodu. Koristeći statističku analizu za različite vrste podataka, linearnu regresiju i studiju slučaja, istraživanje je potvrdilo prvu hipotezu. Koeficijenti dobijeni linearnom regresijom su primenjeni na projekcije STO za globalnu trgovinu u 2020. i 2021. Utvrđeno je da je očekivani pad spoljnotrgovinske razmene Srbije skoro dvostruko veći od svetskog proseka. Druga hipoteza je dokazana analizom ekonomskih uzroka glavnih globalnih trendova, koji su se pokazali kao uglavnom strukturalni,dakle dugoročni.

Ključne reči: međunarodna trgovina, protekcionizam, globalni lanci vrednosti, strana dodata vrednost, Srbija.

\section{Introduction}

Since the beginning of the transition process, all Serbian governments (as well as other Balkan countries) adopted policies to integrate into the world economy as quickly as possible, regardless of the consequences. Among other things, this implies an increase in the share of the services sector at the expense of the share of the real sector in the economy, which affected the deindustrialization of the Serbian economy. As this was not the result of the maturity of the economy, as in the case of developed countries, and given that the decline of industry was sudden and intense, it can be concluded that the deindustrialization in Serbia was premature (Micić, 2015, 21). This is one of the key reasons why Serbia, like other transition economies, has small exports, and has become dependent on imports and foreign capital, which owns vital parts of the economy. The results of the full opening up of an economy are: enormous trade deficit, shutdown of domestic production, takeover of domestic companies by foreign companies, and numerous other economic consequences arising from such conditions.

During the suspension of main supply chains due to the Covid-19 epidemic, the consequences of excessive dependence on imports, whether of finished products or products within global value chains (GVCs) became apparent. It turned out that Serbia does not produce a large number of key products, not 
even those for which it has the conditions, capacities, technology, labor and which it had produced and even exported before the transition.

Dependence on trade in general and trade within GVCs in itself is not necessarily and has not been a problem during the previous decades of intense globalization. However, after decades of growth, all aspects of world trade began to decline after the Global Financial Crisis (GFC) in 2008. The specific aim of the paper is to determine the effects of current trends in international economic relations on Serbian foreign trade. The first of these trends is gradual reduction in the volume of international trade. Another trend that will be analyzed is the rise of trade protectionism, which is partly the cause of the decline in international trade, but, more importantly, a phenomenon that in itself indicates major structural changes in the world economy. The third is the slow but continuous contraction of global value chains (GVCs), expressed by a decrease in foreign value added (FVA) in export products.

The hypotheses are as follows. The first is that in the short term the fall of Serbia's foreign trade may be sharper than global parameters, as a consequence of its excessive openness, and thus the sensitivity of Serbian economy to external changes and disturbances. The hypothesis is further supported by the previous experience of the Global Financial Crisis (GFC), which had stronger negative effects on the Serbian economy than on most of the countries where the crisis arose. For example, during the GFC in the world the growth rate in 2009 was $-1.68 \%$, while in Serbia it was $-2.73 \%$, even the United States, where the GFC originated, had a slightly lower negative growth of $-2.53 \%$.(World Bank, 2019).

The second hypothesis is that the Serbian economy can expect a long-term lower level of total exports, as well as in trade within the GVCs. This statement is supported by the longevity of these trends and their causes. Namely, global economic trends, such as the slowdown in trade growth, the withdrawal or reduction of the activities of multinational companies (MNCs) in many countries and the growth of protectionism, have been going on for many years. The recent lockdowns and declining economic connectivity between states due to the pandemic of Covid-19 are not considered the cause of these phenomena, but they have greatly accelerated these processes.

The research uses methods such as statistical analysis of different types of data, and linear regression to detect the degree of connection between Serbia's foreign trade and world trade. To determine the consequences of the withdrawal trend of GVCs on Serbia, a case study of the automotive industry of Serbia, as a representative of international production, is used.

The review of the literature, i.e. the previous results of research on the causes of declining global trends and its future trends, is followed by a detailed 
description of the methodology used in the paper. The main chapter Results and Discussion is divided into three parts, each of which analyzes the impact of the above key trends in world trade on Serbia's foreign trade.

\section{Literature review}

The decline in international trade in the post-crisis period was analyzed by a relatively small number of authors, bearing in mind that this trend has been present for more than a decade. Lewis and Monarch (2016) have noted that this trend cannot be fully explained by cyclical, transient causes. They were analyzed impact of consumption, real exchange rates and investment on foreign trade of selected large economies. Boz, Bussière and Marsilli (2015) estimated the potential cyclical causes, such as import prices, reduced demand, and crisis-induced change in orientation towards domestic rather than import procurement. The results of its research showed that only half of international trade decline have a cause in these factors. Constantinescu, Mattoo and Ruta $(2015 ; 2016)$ have revealed that one of the structural sources of declining global trade is slower pace of the process of vertical specialization through GVCs. Similar to previous authors, they found that less than $50 \%$ of the decline in international trade can be explained by entrenched factors such as the cyclical slowdown of large economies.

Those three empirical researches summarize all common cyclical factors of the decline in international trade. The results of and suggest that much of the decline in world trade since 2010 is not and cannot be explained by common economic causes. All of these authors have shown that the world economy is exposed to serious structural changes.

According to Georgieva, Loayza \& Mendez-Ramos (2018) the decline in trade growth since the GFC can be explained by two different but highely connected types of factors: transitory and structural. They point out to global value chains as a main structural factor, which initially as a new pattern fostered a steep rise in trade growth. "Lately, however, the maturation and slower pace in growth of global value chains has contributed to the overall trade slowdown." (Georgieva, Loayza \& Mendez-Ramos, 2018, p. 1).

Despite the undivided view on slowing down of the world economy integration, authors have very different perceptions of the future direction of the change. Jacobi (2018) and Evenett (2019) have paid great attention to growing trade protectionism, which they consider one of the important causes of the decline in international trade. However, these authors put protectionism in a broader context, considering it a symptom of structural disturbances of the world 
economy, which lead to economic deglobalization. Bordo (2017) notes the weakening of all key aspects of economic globalization: international trade, including that within production chains, international investment, and the growth of protectionism. He also sees it as a more permanent process, but calls it a "break" in globalization.

\section{Methodology}

Each of the key current trends in international economic relations will be analyzed at the global level, and then their effects on Serbia will be explored. The dependence of Serbia's foreign trade on trends in the world economy is determined by applying linear regression analysis by using the least squares method. Linear regression model has a general form:

$$
Y=\alpha+\beta \mathrm{X}
$$

In the research of the relation between global and Serbian trade trends, it has the following forms:

$$
\begin{aligned}
& \mathrm{St}^{`} 1=\alpha+\beta \mathrm{Wt} ` 1 \\
& \mathrm{St}^{`} 2=\alpha+\beta \mathrm{Wt} 2
\end{aligned}
$$

where St' is a dependent variable for Serbian trade in 2020, Wt' is World trade projected for 2020, 1 is an optimistic and 2 a pessimistic scenario for Serbian and World trade. The data for the shares of trade, exports and imports in GDP covers the period 1995-2019 and its source is World Bank indicators (2019).

In the research of the relation between globally growing protectionism and restrictive measures imposed on Serbia, linear regression takes the next form:

$$
P S=\alpha+\beta P W
$$

where $P s$ is a dependent variable for a number of restrictive measures imposed on Serbia; $P w$ is the total number of restrictive measures imposed on global trade.

Protectionism in this research includes: subsidies (excluding export subsidies), export-related measures (including export subsidies), tariff measures, contingent trade-protective measures and trade-related investment measures. The source of this data is Global Trade Alert, the organization that has been monitoring this phenomenon since the GFC. 
The strong connection between the global phenomenon of the receding of GVCs and Serbian trade within production chains will be analyzed in the case study of the Serbian automotive industry. It is chosen for several reasons. First, it has been exposed to a number of trade restrictions in recent years, both in terms of the sector as a whole and its products (tables 4 and 5). Second, this product group is a typical representative of exports based on involvement in production chains. Third, this is one of the most important groups of Serbian export products. Fourth, according to the WTO (2020b), this sector has suffered the greatest consequences of the Covid-19 epidemic, and the automotive products index (79.7) was the weakest of all, due to the collapsing of production and sales of cars in several major economies.

\section{Results and discussion}

\subsection{The effects of the global decline in foreign trade on the Serbian economy}

The rapid growth of international trade was a key feature of the globalization of the world economy in the aftermath of World War II. The share of trade in the world economy averaged $24 \%$ in the 1960 s, $35 \%$ in the 1970 s, exceeded $50 \%$ of the world GDP in the early 21 st century and reached a historical maximum of $61 \%$ in 2008 (figure 1). 
Figure 1: Share of international trade in GDP, 1970-2018

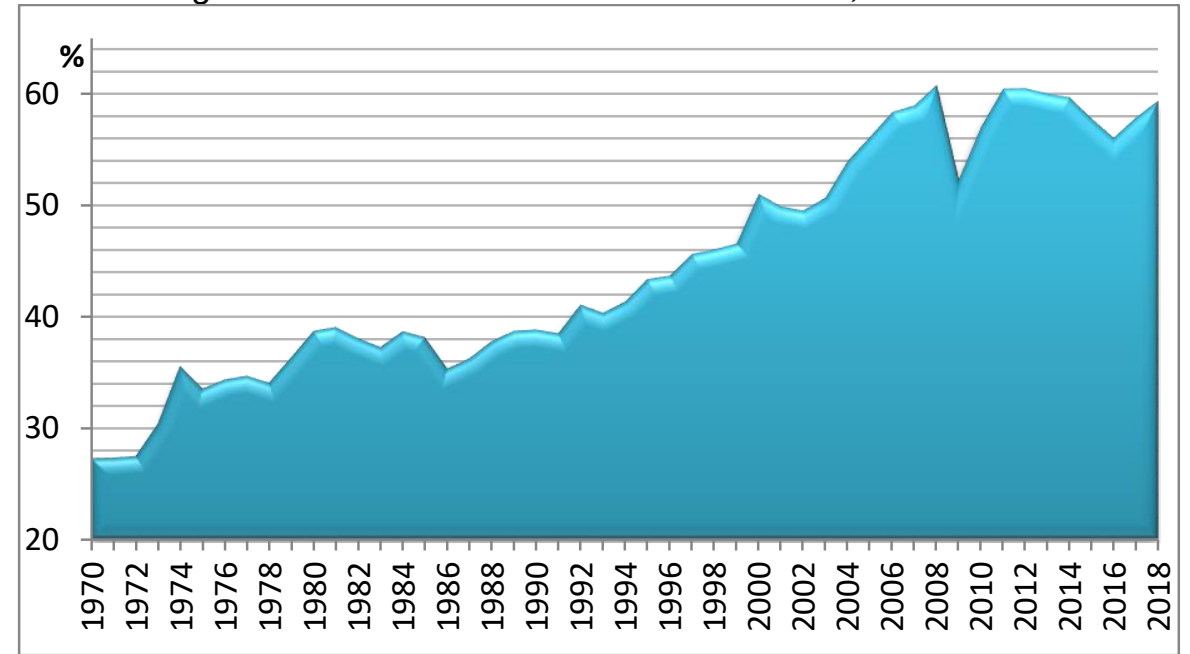

Source: Author according to the World Bank data (2019)

In 2009, the Global financial crisi stopped the growth of international trade at the global level. Except for the next two years, international trade never returned to its previous trend (figure 1 ). The reduction of international trade share in the world economy was not extremely high. Trade was reduced to about $57 \%$ of global GDP in 2018 compared to $61 \%$ of GDP before the GFC. The sensitivity of the Serbian economy to global trends ensues from its high degree of openness in the last two decades. The openness is indicated by the data showing that the share of world trade in global GDP was $58 \%$, while the share of Serbian trade in GDP was 110\% in 2019 (World Bank, 2019). Excessive sensitivity to trends in the world economy shows a very strong conection between Serbia's foreign trade and World trade (table 1).

Table 1. Serbian and Global Trade: models estimation results

\begin{tabular}{|l|r|}
\hline \multicolumn{1}{|c|}{ Variables } & $0.0012^{*}$ \\
\hline Trade & $(3.61)$ \\
\hline Exports & $0.0011^{*}$ \\
& $(2.45)$ \\
\hline Imports & $0.0012^{*}$ \\
\hline Coefficient of determination $\left(\mathrm{R}^{2}\right)$ Trade & $(2.35)$ \\
\hline Coefficient of determination $\left(\mathrm{R}^{2}\right)$ Exports & 0.95 \\
\hline Coefficient of determination $\left(\mathrm{R}^{2}\right)$ Imports & 0.91 \\
\hline
\end{tabular}

Notes * represent significance at $1 \%$, respectively. Standard Error is given in parentheses.

Source: Authors

Industrija, Vol.48, No.4, 2020 
As the results show, the degree of harmonization between Serbian and global changes and trends in international trade is very high.

The determination coefficients are above $90 \%$ in all variables, which means that more than $90 \%$ of Serbian trade, export and import is predictable from these global variables.

In order to estimate the future volume of Serbia's foreign trade, the obtained coefficients will be applied on two forecasted WTO's global trade scenarios, optimistic and pessimistic, in 2020 and 2021.

Table 2. Projections of World trade in 2020 and 2021

\begin{tabular}{|l|r|r|r|r|}
\hline & \multicolumn{2}{|c|}{ Optimistic scenario } & \multicolumn{2}{c|}{ Pessimistic scenario } \\
\hline Year & 2020 & 2021 & 2020 & 2021 \\
\hline Projected change of trade (\%) & -12.9 & 21.3 & -31.9 & 24.0 \\
\hline $\begin{array}{l}\text { Projected value of trade } \\
\text { (billion USD) }\end{array}$ & 43308 & 52532 & 33850 & 41974 \\
\hline
\end{tabular}

Source: Projected change of trade (\%) - WTO (2020b). Projected value of trade - Author's calculation.

These estimates were published in April 2020, so they include the former trade slowdowns from 2018 and 2019, as well as the consequences of the epidemic Covid-19. In 2020 , world trade is expected to decrease by $13 \%$ under the optimistic version and by $32 \%$ under the pessimistic one. Significant trade growth is projected for 2021 , by $21 \%$ and $24 \%$, respectively (Table 2 ).

Figure 2: World trade projections 2020-2021

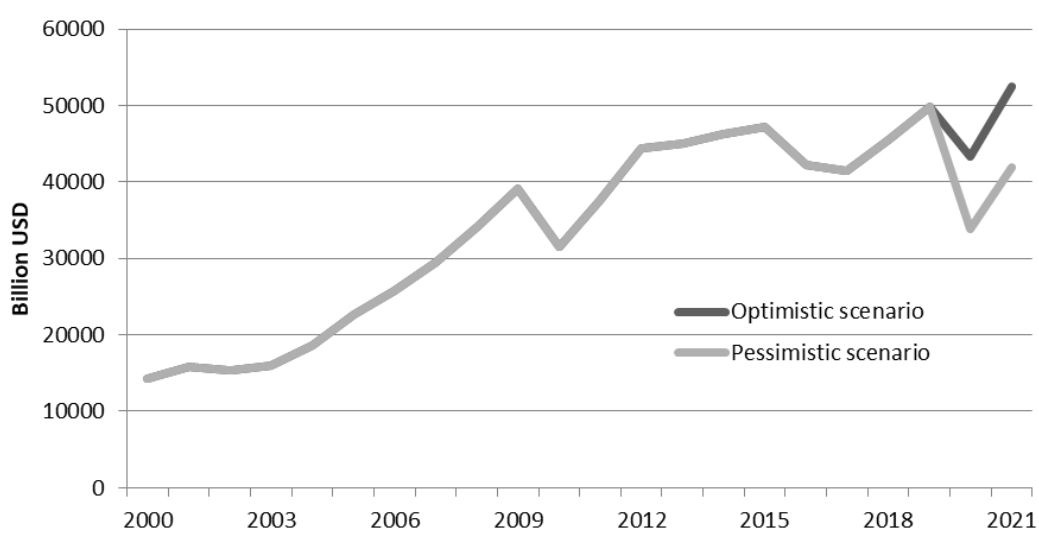

Source: Author according to WTO data (2020b) 
In the optimistic version of the WTO, the growth for 2021 would slightly exceed the already reduced level of trade from 2019, but even in that case, the growth trend is far below the level in the post crisis period. Under the pessimistic scenario, the growth of $24 \%$, although very high, after a decline of $32 \%$ would not provide even the approximate values of trade from the previous period (Figure 2).

By applying the previously obtained coefficients to both scenarios, we get the expected amounts of Serbian trade for 2020 and 2021 (in billion USD).

The obtained results for 2020 are:

$$
\begin{aligned}
& \text { St } 1=-8.86+0.0012 \times 43308=42.75 \\
& \text { St }^{\prime} 2=-8.86+0.0012 \times 33850=31.48
\end{aligned}
$$

Serbian trade in 2019 amounted to 56.69 billion USD, so the expected decrease is $-24.59 \%$ in the optimistic variant and $-44.47 \%$ in the pessimistic one. We see that Serbia in 2020 can expect twice higher rates of negative growth than global ones. Statistically, this is related to the fact that the Serbian economy is also twice as open as the world average.

The results for 2021 are:

$$
\begin{aligned}
& \text { St }^{\prime} 1=-8.86+0.0012 \times 52532=54.18 \\
& \text { St }^{`} 2=-8.86+0.0012 \times 41974=41.51
\end{aligned}
$$

Compared to the calculated values for 2020 , this is an increase of $26.58 \%$, or $32.36 \%$ in 2021 . Under no circumstances can the volume of trade in 2021 reach the value of 2019 .

\subsection{Growing trade protectionism - implications for Serbia}

Another current deglobalizing trend is the sharp rise of protectionism in foreign trade and foreign direct investment. Protectionism can be analyzed through numerous trade restrictive measures with a direct impact on the declining of world trade, but also, it is a sign of deeper structural changes in the world economy. That is why we used the term deglobalizing trend.

After several decades of opening up national economies and intensive efforts by many countries to engage in global economic flows, after the World Financial Crisis, this tendency is taking the opposite direction. The largest and most 
developed economies, which in the previous period were the leaders of globalization, are starting to close to FDI in many sectors, introduce quantitative restrictions and bans, raise tariffs, etc.

The World Trade Organization (WTO) estimates that import restrictions, imposed only in the period from October 2017 to October 2018, resulted in a decrease in international trade by $\$ 480$ billion and restrictions in the period from October 2018 - May 2019 by $\$ 336$ billion (WTO, 2019). New restrictive measures on imports in 2018 were several times higher than the 2012.

According to the Global Trade Alert (GTA), which also includes trade remedies (anti-dumping and other instruments counteracting countries that are considered potentially harmful to the domestic economy) the number of mentioned restrictions is even higher. According to GTA (2020), there are more than 1000 new restrictive measures each year, or more than 2000 in 2018. The 2019 WTO report states the following as a general feature of foreign trade: "During this period, trade tensions continued to dominate as a major feature and contributed to the uncertainty of international trade and the world economy... A record level of new restrictive measures was introduced in the previous period" (WTO, 2019, p. 2). The most affected countries by trade restrictions (at the end of 2019) were: China, Germany, Italy, the USA, France, the United Kingdom, the Republic of Korea, Spain and the Netherlands, each of which is burdened with 4 to 6 thousand of trade and investment restrictive measures (GTA, 2020).

During and after the Covid-19 pandemic, trade protectionism escalated. All countries, despite a number of formal restrictions provided by the WTO and especially the European Union, during 2020, have also provided massive subsidies to large companies, airlines, banks, etc., to save them from bankruptcy.

The number of new restrictive measures imposed on Serbian exports each year after the GFC, ranged between 59 and 170 (GTA, 2020). The number of newly introduced measures in 2019 fell to 88, but this is not encouraging. With former measures still in force, the total number of restrictions on Serbian exports is over 1100.

Table 3. Number of new trade restrictive measures imposed per year on Serbia (2009-2019)

\begin{tabular}{|l|c|c|c|c|c|c|c|c|c|c|c|}
\hline Year & 2009 & 2010 & 2011 & 2012 & 2013 & 2014 & 2015 & 2016 & 2017 & 2018 & 2019 \\
\hline Serbia & 70 & 61 & 59 & 79 & 105 & 109 & 151 & 127 & 130 & 170 & 88 \\
\hline
\end{tabular}

Source: Global Trade Alert (2020) 
More than 200 of them refer to the export of cars and parts and accessories for cars, and this has been the most important export product of Serbia in the last few years. About 90 measures relate to steel exports (the second export product of Serbia) etc.

Table 4. Sectors and products in Serbia most affected by harmful trade interventions

\begin{tabular}{|l|l|r|}
\hline Code & \multicolumn{1}{|c|}{ Name } & Intervention \\
\hline 491 & Motor vehicles; parts and accessories thereof & 214 \\
\hline 412 & Products of iron or steel & 93 \\
\hline 352 & Pharmaceutical products & 91 \\
\hline 8708 & Parts and accessories of the motor vehicles of headings & 175 \\
\hline 3004 & Medicaments & 83 \\
\hline
\end{tabular}

Source: Global Trade Alert (2020)

Moreover, most of these measures are not directed against any particular country, not even Serbia, but are a part of other countries' general restrictive packages in the era of wide economic deglobalization. For example, 60 measures imposed on corn exports from Serbia are a part of the general package of EU import duties from 2017.

Table 5. Trade restrictive measures in Serbia and worldwide: model estimation results

\begin{tabular}{|c|r|}
\hline Variable & $5.55^{*}$ \\
\hline Trade restrictive measures $T R M$ & $(161.39)$ \\
\hline Coefficient of determination $\left(\mathrm{R}^{2}\right)$ & 0.64 \\
\hline
\end{tabular}

Notes * represent significance at $1 \%$, respectively. Standard Error is given in parentheses.

Source: Authors

Coefficient of variable TRM is 5.55 . The coefficient of determination is 0.64 which means that $64 \%$ of restriction imposed on Serbia is predictable by global restriction number.

\subsection{Disruptions of global supply chains and its impact on Serbian economy}

Global supply chains are a specific feature of the world economy from the end of the 20th century. They refer to the separation of the production process of certain goods into production stages, which take place in different countries. As early as the beginning of the 21 st century, there were almost no products made entirely on the territory of one state. The functions and activities of multinational companies (MNCs), as the bearer of international production, have changed

Industrija, Vol.48, No.4, 2020 
significantly. The production of Western companies in developing countries and the import of finished products from them is not a new phenomenon. What is new in the modern process of globalization is that one product crosses several state borders, sometimes several times the same border, during the production process (Stanojević and Kotlica, 2018). A significant reduction in transportation costs has allowed to MNCs to distribute production phases across countries so as to maximize profits.

The involvement of a particular economy in GVCs is measured by foreign value added (FVA). This is the value of imported raw materials, semi-finished products, parts and components, which are incorporated into the product intended for further export. FVA grew rapidly, along with total trade, reaching a maximum before the GFC, and then followed not a rapid but a continuous decline. FVA was globally decreased from 31\% in 2008 to $27 \%$ in 2018 .

In terms of participation in production chains, Serbia is also too dependent on imports. All the largest exporters of Serbian products are companies that are at the same time large importers. They have a small margin between exports and imports or they are net importers. It means that Serbia's position is downstream within GVS's, i.e. products are only assembled in Serbia while almost all components are imported. This is a relatively unfavorable position because domestic added value is very small.

The import of foreign sourced components prevails over Serbian car exports, thus the position of this industry is markedly downstream. In recent years, imports of this industry's products have been increasing, while exports have been declining sharply. These two processes have led to the fact that in 2019 the import and export of motor vehicles, including station wagons (code 8703) have almost the same value, while the import of parts and accessories of the motor vehicles (code 8708) far exceeds the export during the whole period (table 6).

Table 6. Serbia's trade in motor vehicles, parts and accessories (2014-2019)

\begin{tabular}{|c|c|c|c|c|c|c|}
\hline Year & $\begin{array}{c}\text { Code } \\
(\text { HS })\end{array}$ & $\begin{array}{c}\text { Export } \\
(\text { mil USD) }\end{array}$ & $\begin{array}{c}\text { Import } \\
\text { (mil USD) }\end{array}$ & $\begin{array}{c}\text { Code } \\
(\text { HS })\end{array}$ & $\begin{array}{c}\text { Export } \\
\text { (mil USD) }\end{array}$ & $\begin{array}{c}\text { Import } \\
\text { (mil USD) }\end{array}$ \\
\hline 2014 & 8703 & 1780.31 & - & 8708 & 179.02 & 1425.94 \\
\hline 2015 & 8703 & 1300.53 & - & 8708 & 182.14 & 1062.40 \\
\hline 2016 & 8703 & 1231.07 & 537.52 & 8708 & 189.88 & 873.47 \\
\hline 2017 & 8703 & 1058.12 & 446.41 & 8708 & 210.58 & 840.56 \\
\hline 2018 & 8703 & 896.06 & 589.38 & 8708 & 214.82 & 785.35 \\
\hline 2019 & 8703 & 592.17 & 591.61 & 8708 & 207.94 & 510.33 \\
\hline
\end{tabular}

Source: UN Comtrade 
The global trend of withdrawing production of many MNCs from a large number of countries is strongly reflected in Serbia. A sharp decline in the exports of the automotive industry indicates the withdrawal of this production chain. The representative of this industry in Serbia, Fiat Chrysler, has not introduced a single new production line for several years, and is gradually shutting down and removing production from Serbia. To illustrate further the shortening of GVCs and its effects on Serbia, we will state that on a global level, the Peugeot group merged General Motors and Citroen in 2012, then Opel in 2017, and in 2019 Fiat joined this group. This means excluding a large number of manufacturers from the production chains of these companies, or, at best, reducing the range and scope of their participation in the group.

\section{Conclusions and recommendations}

This research is focused and limited on proving the sensitivity and variability of Serbian international trade in relation to global ones. The results indicate the importance and directions of changes in the global economy and the exceptional sensitivity of the Serbian economy to these changes. The first hypothesis about the pronounced sensitivity of the Serbian economy to the global trends has been confirmed, and the results show that the expected decrease in trade is almost twice as high as the global ones.

Another aspect of this research is the assumed permanence of these changes. As the former recent research cited in the literature review has shown, the cause lies only partly in common cyclical changes. The current decline in international economic interaction seems to be a long-term phenomenon, because the basic reasons are structural by its nature. These are the saturation of global markets, general economic uncertainty caused by the GFC, the global convergence of labor prices and technological ranges between developed and growing economies, and so on. These causes then gradually led to the growth of trade protectionism. In addition, the economic upheavals of the Covid-19 pandemic, besides their temporary dramatic effects, also reinforce these downward trends. Due to the pandemic, the borders have been closed for too long so that many trade arrangements cannot be resumed. Furthermore, the pandemic caused a real explosion of protectionism. Huge government interventions suddenly become a common and indisputable right, even an obligation of every state. The protective approach of large economies will further reduce trade.

Reducing all aspects of international economic relations is not necessarily negative for Serbia, i.e. it does not have to be only negative for the Serbian 
economy. Short-term losses are inevitable, but if the lessons of this period are learned, with a proactive approach, the Serbian economy could develop on a somewhat stronger foundation in the future and establish a more stable structure. This refers to a certain degree of reindustrialization and strengthening of the agricultural sector, in order to reduce the very high share of foreign trade in GDP, and thus alleviate the pronounced sensitivity and instability of the economy.

Economic crises are cyclical and inevitable. However, with more significant reliance on domestic economic resources, Serbia would be less exposed to the elements of global currents over which it has no influence. But, reliance on internal resources is a long-term strategy whose elements would need to be explored more deeply. This article does not include specific trade routes and types of goods, which leaves a lot of room for further research. A more detailed analysis could determine which countries whose changes lead to turbulence in Serbian exports, and which in imports. Is it the European Union as a whole or just Germany and Italy as dominant export partners? What are the effects of the disturbance in the neighboring Balkan countries? Finally, it would be important to determine which types of goods or sectors suffer the most from external disturbances. The results of such analyzes would provide a basis for clear economic policies aimed at achieving greater stability of the Serbian economy.

\section{References}

Bordo, M. (2017). The Second Era of Globalization is Not Yet Over: An Historical Perspective. (NBER Working paper, No. 23786). Cambridge, Massachusetts. DOI: $10.3386 / \mathrm{w} 23786$.

Boz, E., Bussière M. \& Marsilli, C. (2015). Recent slowdown in global trade: Cyclical or structural? In B. Hoekman (ed.), The Global Trade Slowdown: A New Normal? London: Centre for Economic Policy Research (pp. 55-71).

Constantinescu, C., Mattoo, A. \& Ruta, M. (2015). Global Trade Slowdown. In B. Hoekman (ed.), The Global Trade Slowdown: A New Normal? London: Centre for Economic Policy Research, (pp. 33-55).

Constantinescu, C., Mattoo, A. \& Ruta, M. (2016). Does the Global Trade Slowdown Matter? Journal of Policy Modeling 38 (4): 711-722.

Eora Global Value Chain Database (1990-2018). UNCTAD. Retrieved May 28, 2020, from https://worldmrio.com/unctadgvc

Evenett, S. (2019). Protectionism, state discrimination, and international business since the onset of the Global Financial Crisis. Journal of International Business Policy, 2 (1), 9-36.

Georgieva, D., Loayza, N. \& Mendez-Ramos, F. (2018). Global Trade: Slowdown, Factors, and Policies, World Bank Technical Paper 12, Retrieved March 29, 2020, 
from

https://www.researchgate.net/publication/324015167_Global_Trade_Slowdown_ Factors and Policies

Global Trade Alert (2020). Database. Retrieved June 11, 2020, from https://www.globaltradealert.org

Jacoby, D. (2018). Trump, Trade, and the End of Globalization, Santa Barbara \& Denver: Praeger.

Keynes, J. M. (1920). The Economic Consequences of the Peace, Retrieved May 21, 2020, from https://www.theglobalist.com/global-man-circa-1913

Lewis, L. \& Monarch, R. (2016). Causes of the Global Trade Slowdown. International Finance Discussion Paper Notes, Washington: Board of Governors of the Federal Reserve System, DOI: https://doi.org/10.17016/2573-2129.25

Micić, V. (2015). Ponovna industrijalizacija i strukturne promene u funkciji ekonomskog razvoja Republike Srbije, Ekonomski horizonti, 17(1), 15 - 31. doi: 10.5937/ekonhor1501015M

Stanojević N., Kotlica S. (2018). Globalisation and Methodology of Researches in International Trade, Industrija, 46 (2), 21-38. DOI: https://doi.org/10.5937/ industrija46-15888

UN Comtrade (2019). Database. Retrieved May 28, 2020, from https://comtrade.un.org/data/

UNCTAD (2018). World Investment Report - Investment and New Industrial Policies, New York: United Nations.

UNCTAD (2019a). World Investment Report - Special Economic Zones, New York: United Nations.

UNCTAD (2019b). Global investment trend monitor, 32, New York: United Nations.

World Bank (2019). World Bank Indicators database. Retrieved from: https://data.worldbank.org/indicator

World Trade Organization (2019). Report on G20 trade measures. WTO, Geneva. Retrieved March 21, 2020, from www.wto.org/english/news_e/news 19_e/report trdev_21nov19_e.pdf

World Trade Organization (2020a). Database. Retrieved March 21, 2020, from https://timeseries.wto.org

World Trade Organization (2020b). Trade set to plunge as COVID-19 pandemic upends global economy, 855press release. Retrieved May 18, 2020, from www.wto.org/english/news_e/pres20_e/pr855_e.htm 